\title{
The frequency of epicardial fat pads detected by chest x-rays in psoriasis patients
}

\author{
Psoriazis hastalarında akciğer grafisi ile tespit edilen epikardiyal yağ yastıkçığı sıkığı
}

\section{Sibel Doğan, ๑ Pelin Esme, ๑ Meltem Gülsün Akpınar*, ๑ Nilgün Atakan}

Hacettepe University Faculty of Medicine, Department of Dermatology; *Department of Radiology, Ankara, Turkey

\begin{abstract}
Background and Design: Psoriasis is a chronic inflammatory skin condition associated with several systemic comorbidities including cardiovascular diseases (CVD). Epicardial fat pad (EFP) is defined as a visceral fat tissue surrounding the heart and coronary vessels. Recent studies revealed epicardial fat thickness, which is also increased in psoriasis, as an early sign of CVD. The aim of this study was to evaluate EFP prevalence and its associations in psoriasis patients.

Materials and Methods: Two hundred thirty-seven psoriasis and 113 control patients were assessed for CVD risk factors, Psoriasis Area Severity Index, body composition parameters and laboratory work-up. Controls were chosen from outpatients who lack any chronic inflammatory skin disease and/or systemic inflammatory disease. Evaluation of chest X-rays were performed by a radiologist who was unaware of clinical data. Results: $42.2 \%$ of psoriasis patients $(n=100)$ and $31 \%$ of controls $(n=35)$ had EFP detected on chest X-ray revealing psoriasis patients had significantly more prevalent EFP than the controls $(p=0.047)$. Prevalence of major CVD risk factors was statistically higher in psoriasis patients $(60 \%, n=142)$ compared to controls $(32 \%, n=36),(p<0.01)$. Psoriasis patients with EFP presented higher prevalence of CVD risk factors (70\%, $4, n=69)$ compared to patients who did not have $\operatorname{EFP}(53 \%, n=67)(p=0.009)$.

Conclusion: EFP is associated with concurrent CVD risk factors and is more prevalent in psoriasis. It can be detected by a first-line imaging method like chest X-ray which is quite cheap, easy to perform and applicable to almost each patient.
\end{abstract}

Keywords: Psoriasis, epicardial, fat pads, psoriatic comorbidity

\section{Öz}

Amaç: Psoriazis, kardiyovasküler hastalıklar (KVH) için bağımsız bir risk faktörü olarak kabul edilmektedir. Epikardiyal yağ yastıkçığı (EYY) ise kalp ve koroner damarları çevreleyen visseral yağ dokusu olarak tanımlanmaktadır. Son dönem çalışmalar, psoriazisli hastalarda artış gösteren epikardiyal yağ kalınlığının KVH için erken bir bulgu olduğuna dikkat çekmektedir. Bu çalısmanın amacı, psoriazis hastalarında EYY ve bununla ilişkili durumların prevalansını ortaya koymaktır.

Gereç ve Yöntem: Bu çalışmada, 237 psoriazis hastası ve 113 kontrol hastası, KVH risk faktörleri, Psoriazis Alan Şiddeti Indeksi, vücut kompozisyon parametreleri ve laboratuvar verileri açısından karşılaştırmalı olarak değerlendirildi. Kontrol grubu kliniğimizde ayaktan hasta polikliniğine başvuran ve hiçbir sistemik enflamatuvar hastalığı olmayan hastalardan seçildi. Akciğer grafileri klinik veriler açısından kör bir radyoloji uzmanı tarafından değerlendirildi.

Bulgular: Psoriazis hastalarının \%42.2'sinde $(n=100)$ ve kontrol grubunun \%31'inde $(n=35)$ akciğer grafisinde EYY tespit edildi. Psoriazis grubunda, EYY sıkığı kontrol grubuna kıyasla istatistiksel anlamlı şekilde yüksekti ( $p=0,047)$. Majör KVH risk faktörleri psoriazis hasta grubunda (\%60, $n=142)$, kontrol grubuna (\%32, $n=36)$ kıyasla istatistiksel olarak anlamlı şekilde yüksek bulundu $(\mathrm{p}<0,01)$. KVH risk faktörleri, EYY olan psoriazis hastalarında $(\% 70, n=69)$, EYY bulunmayan psoriazis hastalarına (\%53, $n=67)$ kıyasla istatistiksel olarak daha yüksek bulundu. $(p=0,009)$.

Sonuç: $\mathrm{EYY}$, mevcut $\mathrm{KVH}$ risk faktörleri ile ilişkilidir ve psoriazis hastalarında kontrol grubuna kıyasla daha sık gözlenmektedir. Sıklıkla ilk sırada kullanılan, göreceli olarak ucuz ve uygulaması basit bir görüntüleme yöntemi olan akciğer grafisi ile EYY'leri rahatlıkla tespit edilebilmektedir. Anahtar Kelimeler: Psoriazis, epikardiyal, yağ yastıkçığı, psoriatik komorbidite

Address for Correspondence/Yazışma Adresi: Pelin Esme MD, Hacettepe University Faculty of Medicine, Department of Dermatology, Ankara, Turkey Phone: +90 5333646576 E-mail: pelinnesme@gmail.com Received/Geliş Tarihi: 26.10.2019 Accepted/Kabul Tarihi: 09.06.2020 ORCID: orcid.org/0000-0001-6339-2185

CCopyright 2020 by Turkish Society of Dermatology and Venereology

Turkderm - Turkish Archives of Dermatology and Venereology published by Galenos Yayınevi. 


\section{Introduction}

Psoriasis is an immune-mediated chronic inflammatory skin disease with systemic comorbidities including cardiovascular and metabolic disorders. Nowadays, psoriasis is considered as an independent risk factor for cardiovascular diseases (CVD) and myocardial infarctus ${ }^{1-3}$. Epicardial fat pad (EFP) is defined as visceral fat tissue surrounding the heart and coronary vessels. Recent studies revealed epicardial fat thickness, which is also increased in psoriasis, as an early sign of CVD ${ }^{46}$. Thus, in this study, we aimed to evaluate EFP prevalence and its associations in psoriasis patients by chest $\mathrm{X}$-rays performed in routine examinations. We hypothesized that EFP will be more frequent in psoriasis patients than healthy controls, concurrent CVD risk factors were also expected to associate with EFP detected by chest X-rays.

\section{Materials and Methods}

\section{Sample and study design}

Data was retrospectively collected from patients' medical charts who were older than 18 years old and had been following with plaque psoriasis in Hacettepe University Department of Dermatology and Venereology between 2014-2017. Disease severity was determined by Psoriasis Area Severity Index (PASI) and body surface area (BSA) involvement. Medical comorbidities related to cardiovascular risk factors including hypertension, obesity, diabetes mellitus, concurrent $C V D$, smoking, hypercholesterolemia and dyslipidemia defined by international guidelines, were recorded. Weight, height, body mass index (BMI) and body composition parameters (including fat\%, fat mass, fat free mass, muscle mass, total body water (tbw), tbw \%, bone mass, basal metabolic rate (BMR), visceral fat rating, ideal body weight, degree of obesity) were assessed by bioelectrical impedance analysis (Tanita-SC32 330ST).

Laboratory examinations including total blood count, comprehensive biochemistry, fasting glucose, serum lipid profile [total cholesterol, lowdensity lipoprotein $(L D L)$, very-low-density lipoprotein, triglyceride, highdensity lipoprotein] and C-reactive protein were also analyzed.

Age and gender matched control group was selected from outpatients who have a diagnosis of non-inflammatory skin disease lacking any systemic inflammatory conditions such as xerosis, tinea pedis, acute urticaria, localized contact dermatitis. All chest X-rays were evaluated by a radiologist who had a substantial speciality in thorax radiology and was blinded from clinical data. Any finding of "mass with fat density obliterating cardiophrenic sinus or the apex of the heart causing loss of appearance in normal cardiac silhouette" (as provided in Figure 1A, B) was accepted as EFP presence.

This study was approved by Hacettepe University Non-Interventional Clinical Research Ethics Committee (approval number: GO 16/404-26). Informed consent was obtained.

\section{Statistical Analysis}

Statistical analysis were performed by using IBM SPSS for Windows, Version 22.0 package program. Continuous variables with and without normal distribution were analyzed by t-test and Mann-Whitney $U$ test, respectively. Categorical variables were shown by number and percentage. The chi-square test, where appropriate, was used to compare these proportions in different groups. Pearson correlation

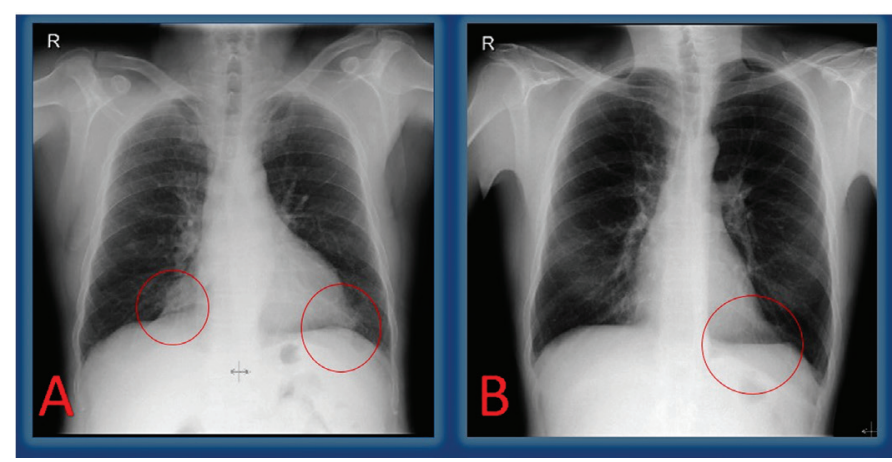

Figure $1 \mathrm{~A}$. Loss of cardiac silhouttes on bilateral cardiophrenic sinuses (red circles) are seen in 59-year-old male psoriasis patient. B. Loss of cardiac silhoutte on left cardiophrenic sinus (red circle) is seen in 45-year-old male psoriasis patient

Table 1. Comparison of characteristics, physical and laboratory findings of psoriasis patients according to epicardial fat pad presence

\begin{tabular}{|c|c|c|c|}
\hline Features & $\begin{array}{l}\text { Psoriasis } \\
\text { patients with } \\
\text { EFP }\end{array}$ & $\begin{array}{l}\text { Psoriasis } \\
\text { patients } \\
\text { without EFP }\end{array}$ & p \\
\hline Age (yrs) & $49.01 \pm 13.37$ & $39.14 \pm 14.41$ & $<0.001$ \\
\hline $\begin{array}{l}\text { Psoriasis diagnosis age } \\
\text { (yrs) }\end{array}$ & $32.90 \pm 15.91$ & $23.20 \pm 13.51$ & $<0.001$ \\
\hline PASI score & $12.29 \pm 10.75$ & $11.94 \pm 8.76$ & 0.70 \\
\hline Body surface area (\%) & $11.08 \pm 10.60$ & $11.92 \pm 12.94$ & 0.148 \\
\hline $\begin{array}{l}\text { Systolic blood pressure } \\
(\mathrm{mm} / \mathrm{Hg})\end{array}$ & $127.24 \pm 14.12$ & $119.56 \pm 18.25$ & 0.064 \\
\hline $\begin{array}{l}\text { Diastolic blood pressure } \\
(\mathrm{mm} / \mathrm{Hg})\end{array}$ & $82.76 \pm 10.14$ & $78.97 \pm 11.01$ & 0.147 \\
\hline Body mass index $\left(\mathrm{kg} / \mathrm{m}^{2}\right)$ & $29.26 \pm 5.80$ & $27.1121 \pm 5.70$ & 0.054 \\
\hline Fat \% & $29.72 \pm 10.44$ & $25.65 \pm 10.16$ & 0.042 \\
\hline Metabolic age (yrs) & $53.04 \pm 17.71$ & $40.39 \pm 16.71$ & $<0.001$ \\
\hline Visceral fat rating (\%) & $10.30 \pm 5.37$ & $7.59 \pm 5.07$ & 0.009 \\
\hline $\begin{array}{l}\text { Total cholesterole } \\
(\mathrm{mg} / \mathrm{dL})\end{array}$ & $219.83 \pm 53.51$ & $199.60 \pm 44.96$ & 0.016 \\
\hline $\begin{array}{l}\text { Low density lipoprotein } \\
(\mathrm{mg} / \mathrm{dL})\end{array}$ & $155.01 \pm 38.94$ & $139.02 \pm 35.46$ & 0.01 \\
\hline $\begin{array}{l}\text { High density lipoprotein } \\
(\mathrm{mg} / \mathrm{dL})\end{array}$ & $46.65 \pm 11.74$ & $47.83 \pm 10.45$ & 0.53 \\
\hline Uric acid (mg/dL) & $5.84 \pm 1.61$ & $5.54 \pm 1.46$ & 0.305 \\
\hline $\begin{array}{l}\text { C-reactive protein } \\
(\mathrm{mg} / \mathrm{dL})\end{array}$ & $0.61 \pm 0.52$ & $0.59 \pm 0.63$ & 0.764 \\
\hline $\begin{array}{l}\text { Red cell distribution } \\
\text { width }\end{array}$ & $14.33 \pm 2.51$ & $13.90 \pm 1.34$ & 0.101 \\
\hline
\end{tabular}

analysis was used to assess the relationships. P-value of less than 0.05 was considered to show a statistically significant result.

\section{Results}

Two hundred thirty-seven patients with psoriasis ( $F / M=95 / 142)$ and 113 sex- and age- matched controls ( $F / M=56 / 57)$ were enrolled for 
the study. No statistically significant difference was found among patients and control group for age $(p=0.816)$ and gender $(p=0.084)$. Totally, $42.2 \%$ of patients $(n=100)$ and $31 \%$ of controls $(n=35)$ had EFP detected on chest $\mathrm{X}$-ray, revealing that patients had significantly more prevalent EFP than the controls ( $p=0.047$ ). Because of EFP presence, loss of cardiac silhouttes on bilateral cardiophrenic sinuses and only on the left side are shown in Figure $1 A, B$, respectively.

The prevalence of major CVD risk factors was statistically higher in psoriasis patients $(60 \%, n=142)$ compared to controls $(32 \%, n=36)$ $(p<0.01)$. Patients with EFP had a higher prevalence of CVD risk factors $(70 \%, 4, n=69)$ compared to the patients who did not have EFP $(53 \%, n=67)(p=0.009)$. The frequency of EPF was found statistically significantly higher in psoriasis patients with major CVD risk factors $48.5 \%(n=69)$ as compared to psoriasis patients without major CVD risk factors $32.6 \%(n=31)(p<0.001)$. Patients with EFP were significantly older and had a significantly later disease onset compared to patients without EFP $(p<0.001, p<0.001)$. Metabolic age and visceral fat ratings measured by a body impedance analyser were also significantly higher in patients with EFP compared to patients without EFP $(p<0.01, p=0.008)$. Patients with EFP also had higher body fat, LDL and cholesterol levels than patients without EFP ( $p=0.042, p=0.014, p=0.009)$ (Table 1). There is no statistically significant difference according to the systolic and diastolic blood pressure measurements $(\mathrm{mmHg})$ between the patients with or without EFP ( $p=0.064, p=0.147)$. No statistically significant relationship was found between disease severity assessed by PASI, BSA and EFP presence $(p>0.05)$.

\section{Discussion}

The relationship between EFP and CVD in patients with psoriasis has not been fully elucidated ${ }^{1,2,46}$. Although the exact mechanism remains unclear, increased EFP prevalence in psoriasis may be due to the chronic systemic inflammatory nature of the disease, the sedentary life style of psoriatic patients and concurrent CVD risk factors ${ }^{1,4,6}$. The cytokine profile of severe psoriasis also leads to visceral fat deposition and associates with several comorbidities including non-alcoholic fatty liver disease ${ }^{7}$.

Today, dermatologists are advised to inform their psoriasis patients regarding CVD association of psoriasis. Appropriate screening measures such as height, weight, blood pressure, blood glucose, hemoglobin A1C, lipid levels, abdominal circumference, and calculation of BMI are also recommended to be performed. Lifestyle modifications, dietary interventions, weight loss and smoking cessation are crucial topics to be discussed. Consultation with cardiologists and other specialists are also advised ${ }^{8}$. Since psoriasis is a common disease, it is not practical to consult all patients to cardiology, so it is the dermatologist's decision to make if a patient with psoriasis may have CVD.

EFP detection is important since it is proposed as a new cardiometabolic risk factor. In our study, EFP associated with concurrent CVD risk factors and was more prevalent in patients with later psoriasis onset, higher body fat percentage and visceral fat rating. Thus, EFP presence may suggest further investigation for CVD especially in this subgroup of patients with late onset psoriasis; obesity may also warrant additional care for the patients.

Although multidetector computed tomography which is costly and required exposure to radiation ${ }^{4,9,10}$ and also echocardiography which can be performed by a cardiologist or radiologist, have been used in several studies for evaluating EFP6,11,12. It was possible to visualize it in psoriasis by using chest $X$-rays which are cheaper, less time consuming and a practical first-line method in the current study. Considering that most of the moderate and severe psoriasis patients use biological agents and so, chest X-ray is required in all of them as an initial and routine examinations. Chest $\mathrm{X}$-ray provides an opportunity to be evaluated for EFP presence without extra cost, extra time and need for another doctor's appointment. Consultation to a cardiologist for echocardiographic evaluation after detection of EFP presence by chest X-ray should be more acceptable algorithm, both financially and in terms of time for patients.

Because of increased prevalence of EFP presence in psoriasis patients, it may raise a suspicion about whether the prevalence of EFP is increased with disease severity of psoriasis which is evaluated by PASI and BSA or not. However the previous study concluded that EFP presence correlated with disease severity in psoriasis patients ${ }^{11}$, our results were not consistent with this finding. Although we could not find any relationship with PS severity indexes and EFP prevalence, addition of major cardiovasculary risk factors clearly increase its risk. Future studies are needed to illuminate these conflicting results.

\section{Study Limitations}

The study has a relatively small number of patients. However, to the best of our knowledge, this current study seems to be the largest study focusing on this topic. One of the other important limitations of our study is the lack of patient follow-up, thus the results show only the pretreatment status of patients and do not provide additional information about the treatment process and disease course. Lack of validation by echocardiography which allows direct visualization of epicardial adipose tissue and also magnetic resonance imaging performed in previous studies is the other limitation of our study.

Further long-term studies are required to better understand the clinical utility and prognostic importance of EFP in patients with psoriasis vulgaris.

\section{Conclusion}

Increased prevalence of EFP in psoriasis patients is a remarkable finding that clinicians should be aware of and this may be considered a risk factor for CVD. EFP can be seen more frequently in patients with hypertension and late-onset psoriasis. We should also be careful about the presence of this finding before systemic drug initiation in psoriasis hence cyclosporine and acitretin treatments may lead to hyperlipidemia and exacerbate an underlying CVD. EFP can be detected by a simple first-line imaging method like chest X-ray which is quite cheap, easy to perform and applicable to almost each and every patient. It shoud be kept in mind that EFP can be recognized in chest X-rays as a predictor of fatal comorbidity associated with coronary artery disease.

\section{Ethics}

Ethics Committee Approval: This study was approved by Hacettepe University Non-Interventional Clinical Research Ethics Committee (approval number: GO 16/404-26).

Informed Consent: It was obtained.

Peer-review: Internally peer-reviewed. 


\section{Authorship Contributions}

Concept: S.D., P.E., M.G.A., N.A., Design: S.D., P.E., M.G.A., N.A., Data Collection or Processing: S.D., P.E., M.G.A., N.A., Analysis or Interpretation: S.D., P.E., M.G.A., N.A., Literature Search: S.D., P.E., M.G.A., N.A., Writing: S.D., P.E., N.A.

Conflict of Interest: No conflict of interest was declared by the authors.

Financial Disclosure: The authors declared that this study received no financial support.

\section{Kaynaklar}

1. Wang $X$, Guo Z, Zhu Z, Bao Y, Yang B: Epicardial fat tissue in patients with psoriasis: a systematic review and meta-analysis. Lipids Health Dis 2016;15:103

2. Lai YC, Yew YW: Psoriasis as an independent risk factor for cardiovascular disease: an epidemiologic analysis using a national database. J Cutan Med Surg 2016;20:327-33.

3. Villasante Fricke $A C$, lacobellis G. Epicardial adipose tissue: clinical biomarker of cardio-metabolic risk. Int J Mol Sci 2019;20:5989.

4. Torres $T$, Bettencourt $N$, Mendonça $D$, et al: Epicardial adipose tissue and coronary artery calcification in psoriasis patients. J Eur Acad Dermatol 2015;29:270-7.
5. Raposo I, Torres T: Psoriasis strikes back! Epicardial adipose tissue: Another contributor to the higher cardiovascular risk in psoriasis. Rev Port Cardiol 2015;34:613-6.

6. Bulbul Sen B, Atci N, Rifaioglu E, et al: Increased epicardial fat tissue is a marker of subclinical atherosclerosis in patients with psoriasis. Br J Dermatol 2013;169:1081-6

7. Doğan S, Menteşoğlu D, Atakan N, Şimşek H: A cross-sectional study investigating association of liver diseases in moderate to severe psoriasis patients. Turkderm-Turk Arch Dermatol Venereology 2019;53:15-8.

8. Menter A, Strober BE, Kaplan DH, et al: Joint AAD-NPF guidelines of care for the management and treatment of psoriasis with biologics. J Am Acad Dermatol 2019;80:1029-72.

9. Torres $T$, Bettencourt $N$, Mendonça $D$, Vasconcelos $C$, Silva BM, Selores $\mathrm{M}$ : Complement C3 as a marker of cardiometabolic risk in psoriasis. 2014;306:653-60.

10. Momose M, Asahina A, Fukuda T, Sakuma T, Umezawa $Y$, Nakagawa $\mathrm{H}$ : Evaluation of epicardial adipose tissue volume and coronary artery calcification in Japanese patients with psoriasis vulgaris. Arch Dermatol Res 2018:45:1349-52.

11. Bacaksız A, Tasal A, Sevgili E, et al: Epicardial fat thickness in patients with psoriasis vulgaris. Turk Kardiyol Dern Ars 2014;42:47-54.

12. Kamath P, Benesh G, Romanelli P, lacobellis G: Epicardial fat: a new therapeutic target in psoriasis. Curr Pharm Des 2019:25:4914-8. 